\title{
Optimization of fast and simple real-time PCR-based method for genotyping the angiotensin converting enzyme-I I/D polymorphism
}

http://dx.doi.org/10.11606/1807-5509201700020393

\author{
João Paulo Limongi França GUILHERME* \\ Salomão BUENO* \\ Lucas Vinicius Machado da SILVA** \\ Antônio Herbert LANCHA JUNIOR* \\ Guilherrme Giannini ARTIOLI*
}

'Escola de Educação Física e Esporte, Universidade de São Paulo, São Paulo, SP, Brasil.

"Educação Física, Pontifícia Universidade Católica do Paraná, Curitiba, PR, Brasil.

\begin{abstract}
The insertion or deletion of 288 bp in intron 16 of the gene encoding for angiotensin converting enzyme-I (ACE) was the first genetic variant associated with physical performance and one of the most studied in the past 15 years. Carries of the deletion in one of its alleles may have higher enzyme activity, which may result in a greater vasoconstrictor response. These individuals may also better respond to strength and power training, as carriers of the insertion may have a greater propensity to respond better to the endurance training. Traditionally, to determine an individual genotype (I/I, I/D or D/D) the conventional PCR is the method used. This method involves the PCR reaction and then gel electrophoresis for the visualization of DNA bands indicating the genotype. For use this methodology on a large scale, as seen in association studies, such as those used to evaluate the influence of genetics in sport, this double process of conventional PCR is not time-effective. This paper aims to present an optimized, fast and efficient method for the genotyping of this polymorphism by real-time PCR, using genomic DNA samples collected from buccal cells. The method discussed in the text was originally proposed in 2001, but its original configuration has limitations in its methodology and uses much of the reagent. Thus, protocol variables such as primer concentration, reaction volume and the resolution of dissociation curve which indicates the genotypes were adjusted. After this adjustments the protocol remained effective with a reduced cost, suitable for use in large-scale studies involving genetic and sport.
\end{abstract}

KEYWORDS: Genetics; Sport; Genotyping; Real-time PCR.

\section{Introduction}

Exercise and sport genomics is a relatively recent and underdeveloped area of research; nonetheless it has gained increasing interest from the scientific community and sports professionals ${ }^{1}$. It has been suggested that exercise and sport genomics has the potential to profoundly transform the way that training programs are prescribed, as well as the way in which general exercise guidelines and talent development in sport are organised ${ }^{2-9}$.

One of the main topics of investigation in this field is the search for relatively common genetic variants, so-called polymorphisms, that hold the potential to enhance physical capacities and/or the responses to training and dietary interventions ${ }^{1}$.
In this regard, several polymorphisms have been identified as being able to benefit muscle strength or aerobic fitness ${ }^{10-11}$. Among these variants, we highlight an insertion/deletion (indel) polymorphism in the Angiotensin Converting Enzyme-I (ACE) gene, the first polymorphism ever associated with physical fitness and sports performance ${ }^{12-13}$. In fact, the ACE indel polymorphism, along with the R577X of the ACTN3 gene, are the two most consistently associated with several aspects of physical fitness and sport performance ${ }^{14}$.

$\mathrm{ACE}$ is an enzyme that cleaves the circulating angiotensin-I; this cleavage gives rise to a highly active oligopeptide, the so-called angiotensin-II. This oligo- 
peptide, in turn, has a broad range of potent systemic effects, all of them culminating in increased blood pressure $^{15}$. Among these effects, of particular interest is peripheral vasoconstriction and the aldosterone-mediated reduction of renal sodium and water excretion ${ }^{16}$. Furthermore, another important effect of ACE is the cleavage of bradykinin, a potent vasodilator, ultimately leading to increased vasoconstriction ${ }^{17}$. In addition to the systemic effects, renin-angiotensin system also has local and tissue-specific effects of great biological importance ${ }^{18}$. In general, these are related to tissue growth and repair after injury ${ }^{19}$, which are relevant in the context of exercise and training.

The ACE gene presents an indel polymorphism (I/D polymorphism) consisting of a 288 base pair-fragment that may be present (allele I - insertion) or absent (allele D - deletion) in the intron 16 (dbSNP rs4340). Studies have shown that ACE plasma levels are highly variable between individuals ${ }^{20}$ and the ACE I/D polymorphism is largely responsible for this variance, since it accounts for $-50 \%$ of the observed variation in this phenotype ${ }^{21}$. More specifically, the $\mathrm{D}$ allele, as opposed to the I-allele, is associated with high ACE activity in plasma and tissues.

A recent study by Domingo, Sturrock and Collins $^{22}$ showed the influence of the ACE I/D polymorphism in endurance performance. These authors evaluated 145 South African elite long-distance triathletes and found a significant difference between genotypes and serum levels of the ACE enzyme. Homozygous for the allele I (genotype I/I) presented significantly lower levels of the ACE enzyme in comparison to $\mathrm{I} / \mathrm{D}$ and $\mathrm{D} / \mathrm{D}$ individuals, which was also associated with better competitive performance. The ACE I/D polymorphism can potentially influence some of the muscle responses to exercise and may increase the likelihood of success in endurance- or strength/power-orientated sports, depending on the individual's genotype ${ }^{19}$. There is a strong body of evidence supporting the role of the I-allele in favouring endurance performance ${ }^{23}$; in contrast, the D-allele has been shown to favour power/strength performance ${ }^{24}$, with the D-allele being often more frequently among power/strength athletes and the I-allele more frequently among endurance athletes ${ }^{25}$.

Genotyping is an essential research tool to any investigation involving genetics, including studies on genomics of exercise and sport. A number different genotyping methods are available, and the choice of the most appropriate method must be based on the type of polymorphism, the number of samples to be genotyped, the number of polymorphisms to be determined in each sample and the equipment/ resources available ${ }^{26}$. Traditionally, I/D polymorphisms, such as the ACE variant, are genotyped by means of conventional PCR followed by visual determination of genotype (i.e., a non-quantitative polymerase chain reaction with multiple primers followed by agarose gel electrophoresis $)^{27-29}$. Despite being low-cost and relatively straightforward, this method involves multiple steps and is time-consuming, making it impractical in studies with very large cohorts, such as genotype-phenotype association studies. Therefore, faster and more accessible techniques have been developed ${ }^{30-33}$.

Lin et al..$^{32}$ proposed a method for genotyping the I/D ACE polymorphism using a fluorophore-based real-time PCR (SYBR Green) followed by allelic discrimination through the analysis of the dissociation (or melting) curve. This method seems particularly attractive for large-scale studies since it is fast, simple and requires one single step. The key point of the method is the dissociation curve performed immediately after the PCR amplification phase; the reaction products are submitted to a preset temperature above the primer's melting temperature (around $60^{\circ} \mathrm{C}$ ) and then gradually heated to $95^{\circ} \mathrm{C}$. As temperature rises, double-strand DNA denatures and turn into single-strand; the dye then dissociates and fluorescence decreases. Given that the PCR reaction produces a different amplicon for each allele and these amplicons denature at different temperatures, genotyping can be determined based on the pattern of denaturation temperatures.

Although simple, genotyping methods based on melting profile may face problems associated with resolution and, consequently, allelic discrimination. The rate at which temperature increases during the dissociation curve (i.e., the resolution of the curve) can be crucial for a clear discrimination of genotypes. In the original report by LIN et al. ${ }^{32}$, this aspect is not explored in detail. Instead, methods' description states that melting curve was performed according to the manufacturer's instructions, which does not allow for an accurate replication of the protocol. Furthermore, the amount of reagents (final reaction volume of $50 \mu \mathrm{l}$ ) makes the method expensive when applied to large cohort studies. As a matter of fact, the method proposed by Liv et al..$^{32}$ has not been used by other research groups ever since. Base on this, the aim of this paper is to further optimise Lin's ACE I/D genotyping protocol, establishing the exact melting curve parameters for optimal allelic discrimination using the least amount of reagents. 


\section{Methods}

\section{Participants}

Genomic DNA samples from 150 individuals were analysed. All individuals volunteered for a larger cohort study that is being conducted in our laboratory and aims to assess the polygenic profile of Brazilian athletes in comparison to non-athletes (controls). All samples herein analysed were from the existing non-athletes cohort and all participants were fully informed about the objectives, risks and benefits associated with participation in the study before signing the consent form. All procedures were approved by the Research Ethics Committee of the School of Physical Education and Sport, University of São Paulo.

\section{Experimental approach}

After the extraction of genomic DNA from mouthwash samples, we optimize the previously published method by LIN et al. ${ }^{32}$ for genotyping the ACE I/D polymorphism. The following protocol variables were modified: primer concentration and absolute amount, dissociation curve resolution and final reaction volume. After optimization, the protocol's validity was tested by comparing the ACE I/D genotypes with those obtained using the conventional PCR method. To that end, genomic DNA samples from 150 individuals were genotyped using both methods and the concordance of genotypes between methods was recorded. All samples were specifically coded for each method in order to ensure that, when genotyping, the assessor was blind to the genotype obtained with each method. To assess whether the real-time PCR-based genotyping is free of subjective interpretations (i.e., method's objectivity), we also evaluated the agreement of genotype determination between two independent investigators; one single investigator performed real-time PCR whilst allelic discrimination was undertaken by two investigators.

\section{Sample collection and genomic DNA extraction}

Genomic DNA was extracted from buccal mucosa cells obtained with mouthwash. After briefly cleaning their mouths using saline solution, the participants were instructed to scrape their teeth on their tongue and cheeks in order to augment the amount of buccal cells available for collection. Following this, approximately $10 \mathrm{ml}$ of saline prepared with DNA- and
DNAse-free water was provided to the volunteers and they were requested to perform a vigorous mouthwash for $\sim 15 \mathrm{~s}$; the oral rinse was then collected in a DNAand DNAse-free $50 \mathrm{ml}$ conical tube. The entire procedure was repeated twice and the samples were kept frozen at $-20^{\circ} \mathrm{C}$ for further DNA extraction.

To extract genomic DNA, the conical tubes containing mouth rinses were centrifuged at $7000 \mathrm{G}$ for 10 minutes at $4^{\circ} \mathrm{C}$ to separate buccal cells from saline and mucus. After discarding the supernatant, the maximum amount of cells was transferred to a $2.0 \mathrm{ml}$ microtube and $500 \mu \mathrm{l}$ of lysis buffer (100 mM Tris-HCl pH 8.0, 0.5 mM EDTA, $0.2 \mathrm{M} \mathrm{NaCl}$, $0.2 \%$ SDS, $50 \mathrm{mg}$ Proteinase K) was added; the cells were then stirred for at least 8 hours at $55^{\circ} \mathrm{C}$. After incubation, $100 \mu \mathrm{l}$ of $5 \mathrm{M} \mathrm{NaCl}$ solution was added, microtubes were then vigorously vortexed for 20 seconds and the nucleic acids were separated from cellular debris through density gradient by adding $300 \mu \mathrm{l}$ of chloroform and centrifuging at $5000 \mathrm{G}$ for 5 minutes at $4^{\circ} \mathrm{C}$. Following centrifugation, the upper layer of the supernatant $(-700 \mu \mathrm{l}$ on average) containing nucleic acids was transferred to a new $1.7 \mathrm{ml}$ microtube. The nucleic acids were then precipitated by adding approximately $700 \mu \mathrm{l}$ of ice-cold absolute ethanol and then separated by centrifuging at 3000 $\mathrm{G}$ for 5 minutes at $4^{\circ} \mathrm{C}$. After removal of the supernatant, the pellet containing purified nucleic acids was resuspended in 100-300 $\mu$ l of TE (Tris- EDTA) DNA- and DNAse-free buffer. The purified DNA was then quantified by spectrophotometer (NanoDrop ND $2000^{\circ}$ ) and stored at $-20^{\circ} \mathrm{C}$ until analysis.

\section{ACE I/D polymorphism genotyping by real-time PCR and melting curve analysis}

PCR reaction was performed in a 0.2 or $0.1 \mathrm{ml}$ microtube containing: SYBR Green PCR Master Mix (Applied Biosystems ${ }^{\circ}$ ) (50\% of the final reaction volume), a set of three primers, 15 ng of genomic DNA; ultrapure DNA- and DNAse-free water (Invitrogen ${ }^{\circ}$ ) was added to complete the final reaction volume. Further details of this protocol, such as the concentration of the primers used and the final volume of the reaction will be discussed in the following sections. The reaction was conducted using the thermal cycler Rotor-Gene $\mathrm{Q}\left(\right.$ Qiagen $^{\odot}$ ). The sequences of the primers were: PRIMER 1:5'- CATCCTTTCTCCCATTTCTC-3'; PRIMER 2: 5'- TGGGATTACAGGCGTGATACAG-3' and PRIMER 3: 5'- ATTTCAGAGCTG- 
GAATAAAATT-3'. The PCR reaction was carried out with the following temperature cycling conditions: initial denaturation at $95^{\circ} \mathrm{C}$ for 10 minutes followed by 40 cycles of $95^{\circ} \mathrm{C}$ for 15 seconds and $55^{\circ} \mathrm{C}$ for 1 minute. After DNA amplification, the resulting PCR products (amplicons) were subjected to the dissociation curve (melt curve); the samples were cooled down to $60^{\circ} \mathrm{C}$ and then the temperature was slowly increased up to $95^{\circ} \mathrm{C}$. The fluorescence intensity $(\mathrm{F})$ generated by SYBR Green fluorophore was continuously recorded during temperature elevation and the signal was plotted as a function of temperature $(\mathrm{T})$ to obtain the dissociation curve for each sample. The dissociation peaks were then generated by plotting the negative derivative of fluorescence in relation to temperature as a function of temperature (-dF/dT vs $\mathrm{T})$. Genotyping was then performed by visual inspection of the dissociation curve. The product of the I-allele amplification is a 66bp amplicon resulting from the anealling of PRIMER 2 and PRIMER 3 and its dissociation peak occurs at a lower temperature than the dissociation peak of the D-allele product, which is the result of the combination of PRIMER 1 and PRIMER 3, and generates an 83bp amplicon. Samples from heterozygous individuals present two dissociation peaks. FIGURE 1 shows the dissociation curve for three individuals (one example of each genotype), as proposed by Lin et al. ${ }^{32}$.

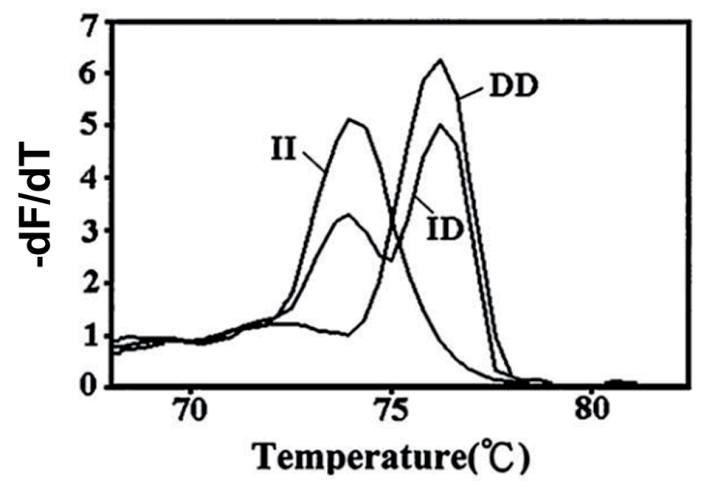

FIGURE 1 - Examples of genotyping results for I/D ACE polymorphism by real-time PCR as proposed by LIN et al. ${ }^{32}$.

\section{Results and discussion}

\section{Genomic DNA extraction}

The DNA samples extracted according to the protocol herein described were quantified and assessed

\section{ACE I/D polymorphism genotyping by conventional PCR}

This protocol follows a previously described method $^{34}$. The reaction was undertaken in a $0.2 \mathrm{ml}$ microtube containing: $1 \mu \mathrm{l}$ of each primer at $10 \mathrm{mM}, 2 \mu \mathrm{l}$ of reaction buffer (10X OneTaq Standard Reaction Buffer - New England BioLabs $\left.{ }^{\circ}\right), 1.6 \mu \mathrm{l}$ of the dNTP mix $(10$ $\mathrm{mM}), 0.2 \mu \mathrm{l}$ of polymorase enzyme (One Taq ${ }^{\circ}$ DNA Polymerase - New England BioLabs $\left.{ }^{\oplus}\right), 15$ ng of DNA sample and ultrapure DNA- and DNAse-free water (Invitrogen ${ }^{\oplus}$ ) up to the final volume of $20 \mu \mathrm{l}$. A set of two primers was used: 5'-TGGAGACCACTCCCATCCTTTCT-3' and 5'-GATGTGGCCATCACATTCGTCAGAT-3'. The temperature cycling conditions were as follows: initial denaturation at $94^{\circ} \mathrm{C}$ for 5 minutes and 35 cycles of $94^{\circ} \mathrm{C}$ for 30 seconds, $58^{\circ} \mathrm{C}$ for 30 seconds and $68^{\circ} \mathrm{C}$ for 1 minute. After 35 cycles, the reaction was subjected to a final extension period at $68^{\circ} \mathrm{C}$ for 5 minutes. The amplicons resulting from the amplification of $\mathrm{D}$-allele are of $190 \mathrm{bp}$ in length and those resulting from the I-allele are of $490 \mathrm{bp}$ in size. These fragments were separated on a $1.5 \%$ agarose gel and visualized using the NANCY-520 dye (Sigma-Aldrich ${ }^{\oplus}$ ), as shown in FIGURE 2.

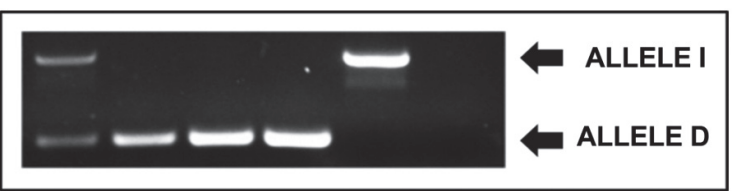

FIGURE 2 - Results of agarose gel electrophoresis for genotyping the I/D ACE polymorphism by conventional PCR. Homozygous individuals have only 1 band, which is corresponding to one of the two alleles that exist (I or D). Heterozygous individuals have two bands, each band corresponding to one allele of each genetic variation.

by spectrophotometry (NanoDrop ND $2000^{\circ}$ ). The mean concentration $( \pm S D)$ found in the samples was $625.27 \pm 243.42 \mathrm{ng} / \mu \mathrm{l}$ in a final volume of 200 $\mu$ l. Nucleic acids and proteins have a maximum 
absorbance at 260 and $280 \mathrm{~nm}$, respectively. The ratio of these two absorbance values $(260 / 280)$ is used to assess sample's purity, with values between 1.8 and 2.0 indicating the sample is pure; our samples were shown to be $260 / 280$, with a value of 1.99 ( \pm 0.06 ). Absorbance values obtained at 230 $\mathrm{nm}$ indicate the presence of contaminants, such as chloroform and salts and the 260/230 ratio is used to assess the presence of these; values close to 2.0 are obtained when the sample is considered pure. In our samples, we observed a value of $1.97( \pm 0.16)$ for the $260 / 230$ ratio.

\section{Application of the genotyping protocol proposed by Lin et al. (2001) with redu- ced amount of primers}

As a first attempt to optimize the protocol, we tested different primer concentrations. LiN et al. ${ }^{32}$ used primer quantities of $50-100 \mathrm{pmol}$ in a $50 \mu$ final reaction, which gives a concentration of $1-2 \mathrm{pmol} / \mu \mathrm{l}$, or a minimum of $1000 \mathrm{nM}$ and a maximum of $2000 \mathrm{nM}$. Here we tested primer concentrations ranging from $200 \mathrm{nM}$ to $800 \mathrm{nM}$.

According to LIN et al..$^{32}$, the concentration of PRIMER 2 should be twice the concentration of the PRIMER 1 and PRIMER 3. With that in mind, we ran two sets of tests, each set using a specific concentration of primers, as follows: test 1) 200 $\mathrm{nM}$ was used for primers 1 and 3 and $400 \mathrm{nM}$ for PRIMER 2; test 2) $400 \mathrm{nM}$ for primers 1 and 3 and
$800 \mathrm{nM}$ for PRIMER 2. A clear exponential signal was obtained in both tests (FIGURE 3, panel A), indicating that DNA amplification occurred even when lower primers concentration was used. In addition, we could confirm the presence of peaks in the dissociation curves (FIGURE 3, panel B), which furthers confirms that DNA amplification of one single target region has occurred regardless of primer concentration. Although the use of concentration of test 1 yielded a slightly lower fluorescence signal (FIGURE 3, panels A and B), both signals were very close and similar, which led us to conclude that the first concentration (200-400 nM; reduction of 80\% of the proposed by Lin et al. $\left.{ }^{32}\right)$ is sufficient for the amplification of the target DNA region.

Following this, using the concentration 1 described above (200-400 nM), we sought to evaluate the efficiency of the reaction to genotype 3 different samples whose genotypes were known: I/I, I/D and $\mathrm{D} / \mathrm{D}$. As shown in FIGURE 3 (panel C), peaks were observed in the dissociation curve, which were perfectly distinguishable between samples I/I and $\mathrm{D} / \mathrm{D}$. However, peaks from the I/D sample were not present, unlike what it would be expected (only a single peak at a different temperature of alleles I and D was observed, rather than a double peak coincident with the temperature of the alleles I and D). Based on these results, the next step was the identification of the optimal parameters of the dissociation curve for allelic discrimination (resolution of the dissociation curve).

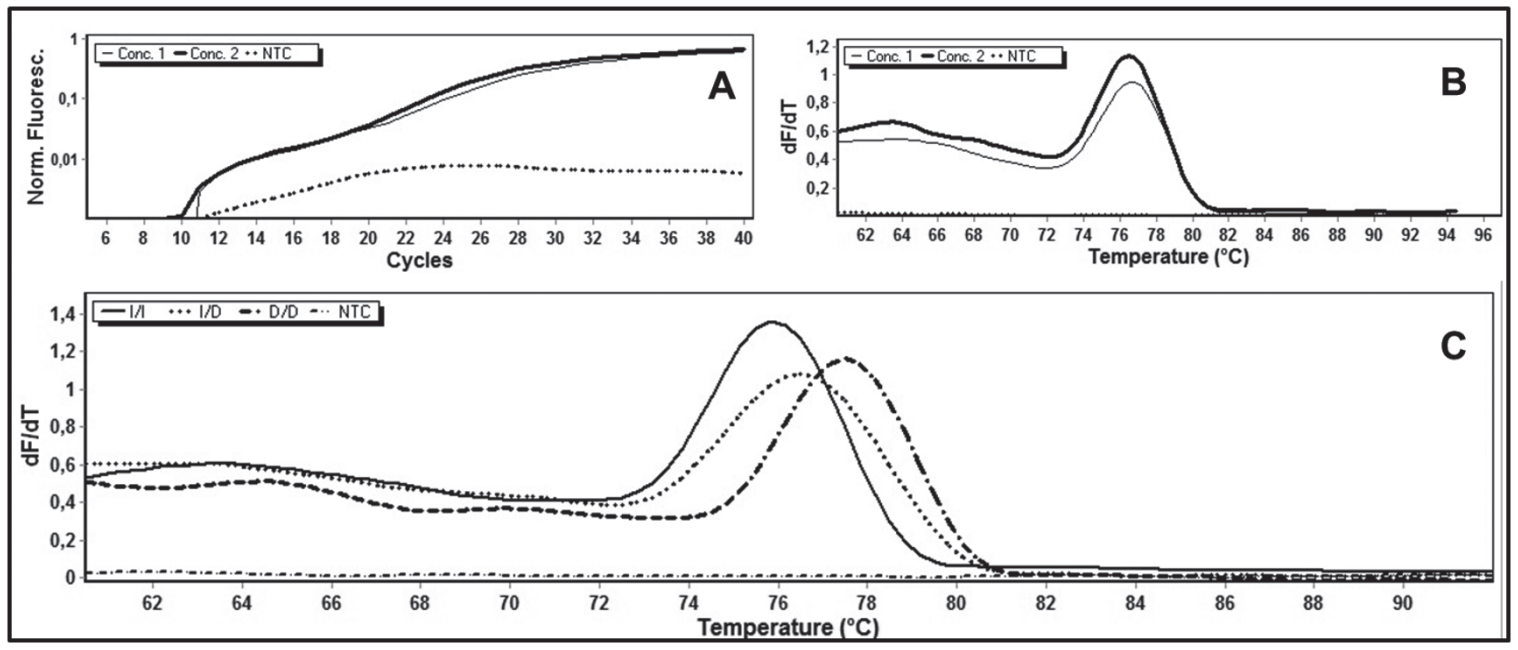

FIGURE 3 - Using the proposed method by LIN et al..$^{2}$, but with a reduced primer concentrations than originally proposed. Fields A and B represent the reaction of the same sample for PCR (heterozygous) using two different concentrations of the primers. The $\mathrm{C}$ field is the dissociation curve for 3 different samples (one for each genotype). Final reaction volume $=40 \mu \mathrm{l}$. 


\section{Exploration of the best resolution profile for the dissociation curve}

The original work of Lin et al..$^{32}$ does not specify the parameters of the dissociation curve for allelic discrimination. Therefore, we chose to start using the default thermal cycler protocol: samples are cooled to $60^{\circ} \mathrm{C}$ and then heated to $90^{\circ} \mathrm{C}$, rising $1^{\circ} \mathrm{C}$ at every 5 seconds, with fluorescence being read after every $1^{\circ} \mathrm{C}$ increase. Since a double peak in the heterozygous sample (I/D) was not observed using this parameter (FIGURE 4, panel A), other resolutions were tested. To further enhance melting resolution, we tested the following increases in temperature, rising from $60^{\circ} \mathrm{C}$ until $90^{\circ} \mathrm{C}: 0.7^{\circ} \mathrm{C}, 0.5^{\circ} \mathrm{C}, 0.4^{\circ} \mathrm{C}, 0.35^{\circ} \mathrm{C}, 0.3^{\circ} \mathrm{C}$, and $0.1^{\circ} \mathrm{C}$. Fluorescence intensity was recorded after every temperature increase, which occurred every 2 seconds (FIGURE 4, panels B to G).
As shown in FIGURE 4, the increase in melting resolution from $1^{\circ} \mathrm{C}$ to $0.7^{\circ} \mathrm{C}$ was not sufficient to distinguish the alleles in heterozygous samples (panel B). However, when temperature increases were between $0.5^{\circ} \mathrm{C}$ and $0.3^{\circ} \mathrm{C}$, a clear double peak was observed in the heterozygous samples, allowing for a clear identification of the three possible genotypes (panels $\mathrm{C}$ to $\mathrm{F}$ ). Interestingly, very high resolutions (increases of $0.1^{\circ} \mathrm{C}$ ) generated large amounts of noise, making it difficult to identify genotypes (panel $\mathrm{G})$. These results allow us to conclude, therefore, that rises between $0.5^{\circ} \mathrm{C}$ (medium resolution) and $0.3^{\circ} \mathrm{C}$ (high resolution) at every 2 seconds are suitable for the dissociation curve, with rises of $0.35^{\circ} \mathrm{C}$ at every 2 seconds providing the clearest curves for correct genotype identification. Therefore, all further tests were carried out using these settings.

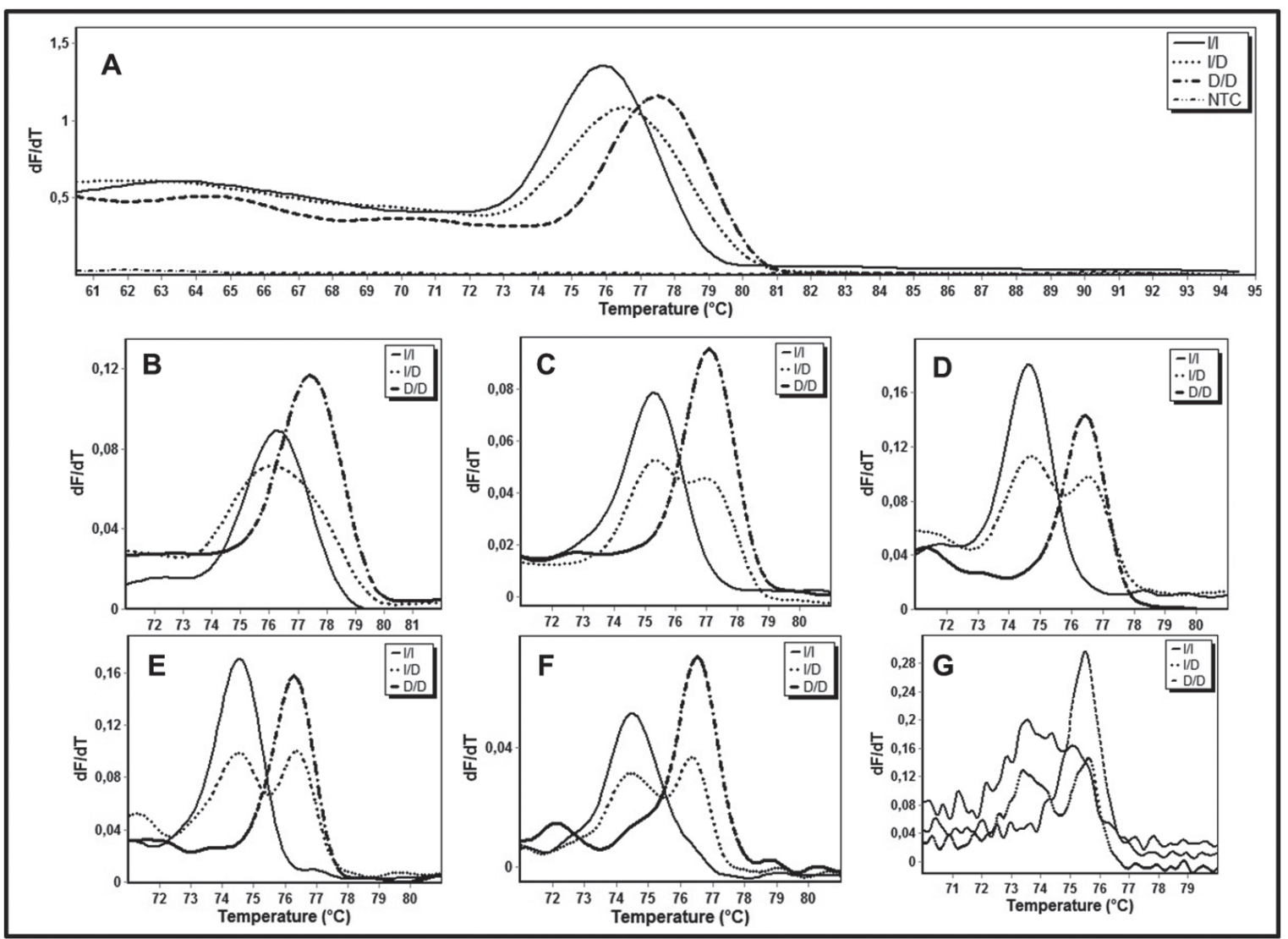

FIGURE 4 - Optimization of the dissociation curve. Different resolutions of increase in temperature during dissociation curve were tested. $\mathrm{A}=$ the temperature was raised at $1^{\circ} \mathrm{C}$ every 2 seconds; $\mathrm{B}=$ temperature rise of $0.7^{\circ} \mathrm{C}$ every 2 seconds; $\mathrm{C}=$ temperature rise of $0.5^{\circ} \mathrm{C}$ every 2 seconds; $\mathrm{D}=$ temperature rise of $0.4^{\circ} \mathrm{C}$ every 2 seconds. $\mathrm{E}=$ temperature rise of $0.35^{\circ} \mathrm{C}$ every 2 seconds; $\mathrm{F}=$ temperature rise of $0.3^{\circ} \mathrm{C}$ every 2 seconds; $\mathrm{G}=$ temperature rise of $0.1^{\circ} \mathrm{C}$ every 2 seconds. 


\section{Optimization of primer concentration and final volume reaction}

The original protocol described by Lin et al. ${ }^{32}$ recommends that the concentration of PRIMER 2 should be two times higher than that of the other primers. Taking into account that this makes the procedure more expensive, we aimed to test the effects of reducing the concentration of PRIMER 2 on the PCR efficiency. Thus, three different re- actions parameters were tested in two homozygous samples (I/I and D/D), as follows: 1) using the 1:2:1 ratio (200, 400 and $200 \mathrm{nM}$ for primers 1, 2 and 3, respectively); 2) using the 1:1:1 ratio and "low concentration" (200 nM for all primers); and 3) using the proportion 1:1:1 and "high concentration" (400 $\mathrm{nM}$ for all primers). As shown in FIGURE 5, the reaction has efficiently occurred in all conditions tested, indicating that the concentration of $200 \mathrm{nM}$ for all primers ("low concentration") is the best choice.
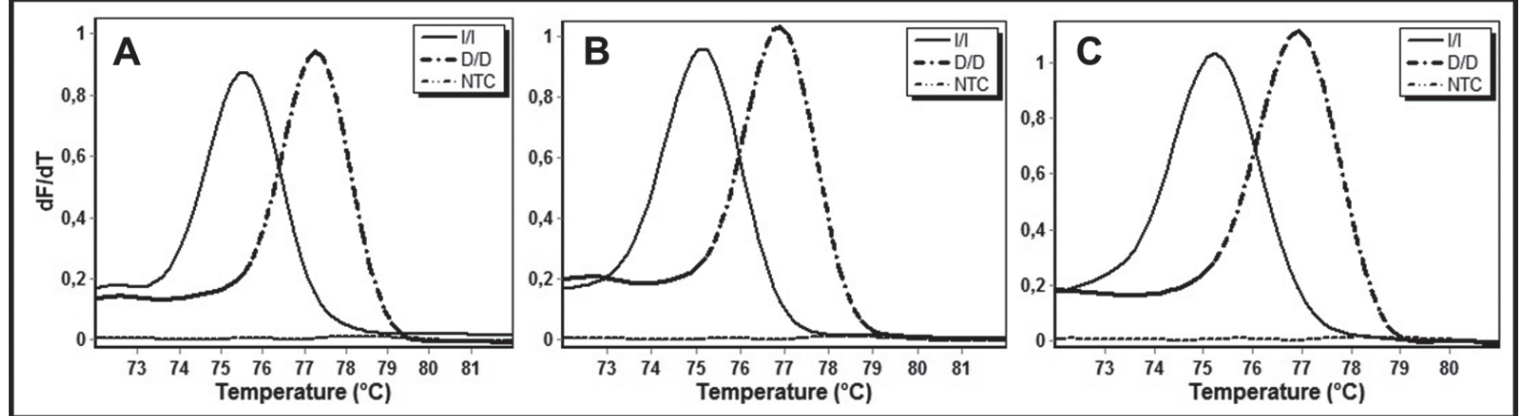

FIGURE 5 - Primer curve. Comparison of the PCR reaction for two samples (one of each homozygous genotype) at three different concentrations of primer. $\mathrm{A}=200 \mathrm{nM}$ for all three primers; $\mathrm{B}=1: 2: 1$ ratio (200: 400: $200 \mathrm{nM}$ for all three primers, respectively); $\mathrm{C}=400 \mathrm{nM}$ for all three primers.

The last parameter of the reaction to be optimized was the final volume, since its reduction would also reflect a significant overall cost reduction. Lin et al. 32 used a final volume of $50 \mu \mathrm{l}$. In order to assess the feasibility of the procedure with lower volumes, we tested the efficiency of the reaction using 40, 20 and $10 \mu \mathrm{l}$ as the final volumes. Allelic discrimination was perfectly identifiable using both 40 and $20 \mu \mathrm{l}$ (FIGURE 6, panels A and B, respectively), with no signal (FIGURE 6, panel C) and dissociation peaks (FIGURE 6, panel D) being detected with the final volume of $10 \mu \mathrm{l}$. Therefore, the use of $20 \mu \mathrm{l}$ of final volume for each reaction of PCR is the best option to discriminate the ACE I/D polymorphism genotypes. It is noteworthy that these results were obtained in PCR tubes with maximum capacity of $200 \mu \mathrm{l}$, as well in tubes with maximum capacity of $100 \mu \mathrm{l}$, with no differences being found between them.

\section{Validation of the optimised genotyping method}

Of the 150 samples assayed, 4 were not successfully genotyped using the conventional PCR meth- od, though all samples were successfully genotyped using the real-time PCR method; therefore, only 146 samples were considered for comparison. Out of these 146, genotype identification was identical in 145 samples (99.3\% agreement), meaning that we observed disagreement between methods in only one sample. In this case the conventional PCR indicated the $\mathrm{D} / \mathrm{D}$ genotype, while real-time PCR indicated $\mathrm{I} / \mathrm{D}$ genotype.

Due to a large difference in the length of amplicons between polymorphic alleles, the conventional method has been considered susceptible to mistyping, since some individuals may be wrongly identified as $\mathrm{D} / \mathrm{D}$ instead of $\mathrm{I} / \mathrm{D}$, according to the preferential amplification of the $\mathrm{D}$ allele ${ }^{29,35}$. To avoid this problem, the conventional method is generally followed by a second PCR only for those samples initially classified as $\mathrm{D} / \mathrm{D}$; this confirmatory PCR is performed using specific primers for the I allele. In the present study, it is likely that only discordant samples were a classic case of mistyping. However, this could only be confirmed by sequencing or by running the second conventional PCR with specific primers, which was not carried out in this investigation. 

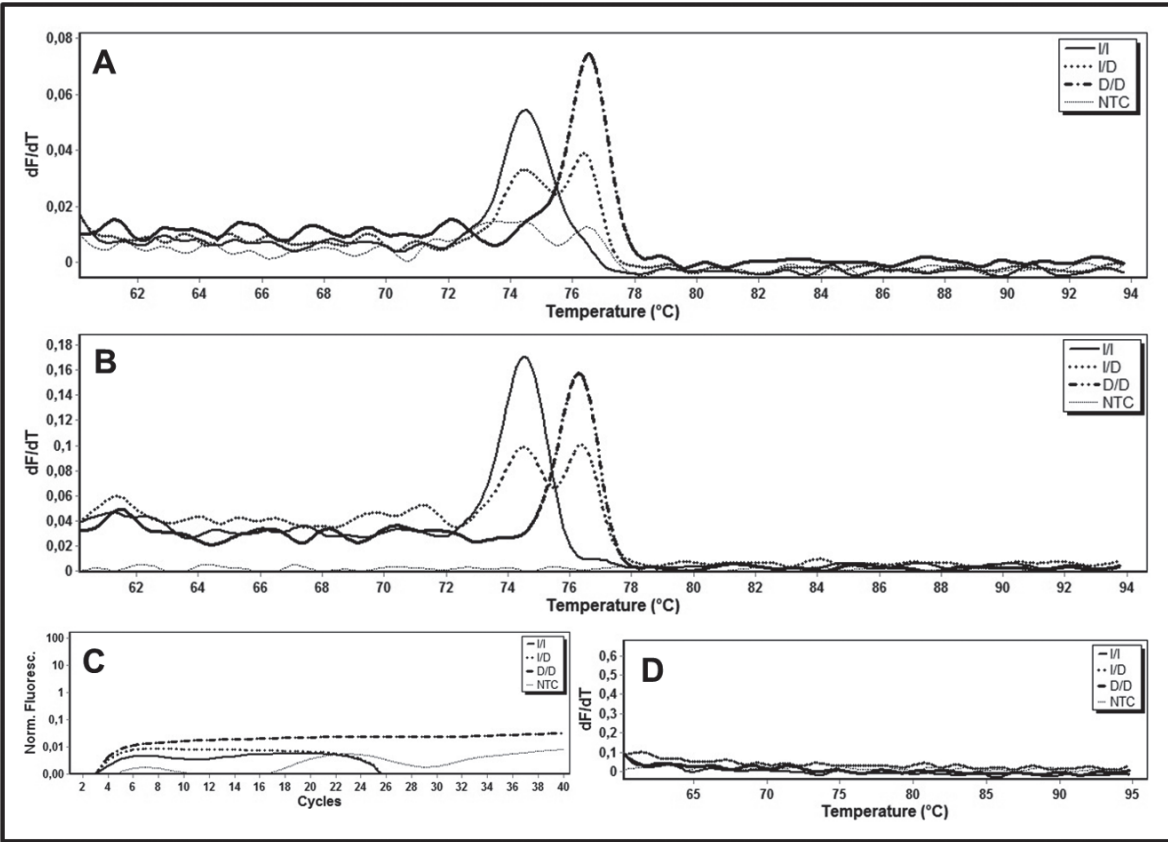

FIGURE 6 - Comparison of PCR reaction with different final volumes. A = dissociation curve for three samples (one of each genotype) carried out with a final volume of $40 \mu \mathrm{l}$; B = dissociation curve for three samples (one of each genotype) carried out with a final volume of $20 \mu \mathrm{l}$; $=$ the fluorescence signal during the 40 cycles of DNA amplification for three samples (one of each genotype) carried out with a final volume of $10 \mu \mathrm{l}$; D = dissociation curve for three samples (one of each genotype) carried out with a final volume of $10 \mu \mathrm{l}$.

In the table below (TABLE 1) we can see the frequency of genotypes for each method (real-time PCR vs. conventional PCR) in the 146 samples compared. For the real-time PCR genotyping, the experiments were performed by two independent investigators and were conducted in two independent PCR machines. Researcher A use the thermal cycler Rotor-Gene Q $\left(\right.$ Qiagen $^{\oplus}$ ) and the fluorophore SYBR ${ }^{\oplus}$ Green PCR Master Mix (Applied Biosystems ${ }^{\circ}$ ). Researcher B use the thermal cycler Rotor-Gene 6000 (Corbett Life Science) and the fluorophore Platinum ${ }^{\oplus} \mathrm{SYBR}^{\oplus}$ Green qPCR SuperMix-UDG (Applied Biosystems ${ }^{\odot}$ ). No differences were found in real-time PCR genotyping between the two independent researchers.

TABLE 1 - Comparison of methods used for genotyping the I/D ACE polymorphism. The data are presented as \% (n).

\begin{tabular}{cccc}
\hline Genotype & $\begin{array}{c}\text { Real-time PCR } \\
\text { Researcher A }\end{array}$ & $\begin{array}{c}\text { Real-time PCR } \\
\text { Researcher B }\end{array}$ & Conventional PCR \\
\hline D/D & $47 \%(68)$ & $47 \%(68)$ & $46 \%(67)$ \\
D/I & $33 \%(49)$ & $33 \%(49)$ & $34 \%(50)$ \\
I/I & $20 \%(29)$ & $20 \%(29)$ & $20 \%(29)$ \\
Total & $100 \%(146)$ & $100 \%(146)$ & $100 \%(146)$ \\
\hline
\end{tabular}

Thus, the objectivity analysis of genotype identification showed a perfect $100 \%$ agreement between two independent researchers, indicating that the method herein optimised is objective and free of subjective misinterpretations.
One last test we performed is related to the dye used for genotyping, with two different fluorophores being used, as follows: SYBR ${ }^{\oplus}$ Green from Applied Biosystems ${ }^{\circledast}$ and from Sigma-Aldrich ${ }^{\oplus}$ (LuminoCt SYBR Green qPCR ReadyMix). Gen- 
otype determination were identical with both dyes and FIGURE 7 shows a representative dissociation curve for each genotype generated using the two different fluorophores.

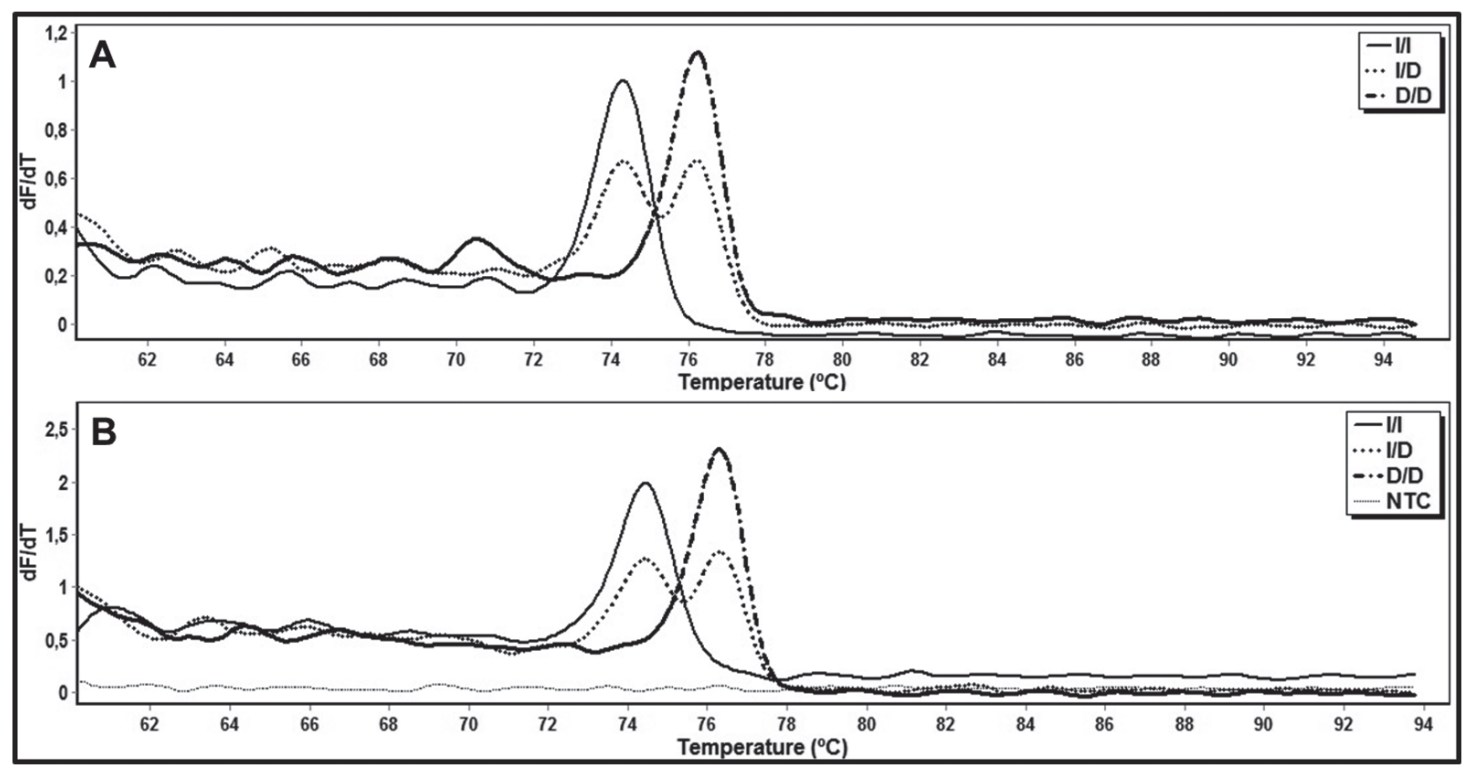

FIGURE 7 - Dissociation curve for the determination of the ACE I/D polymorphism genotypes using different dyes. $\mathrm{A}=$ Fluorophore 1; B = Fluorophore 2 (the names of the fluorophores were blinded).

Based on the results presented here, we conclude that the optimized protocol is objective, reliable, quick and relatively inexpensive, ideal characteristics for studies involving the genotyping of large cohorts, as is the case of association studies in the field of physical education and sport. However, it is worthy to note that the protocol optimization relies on the fine adjustment of the melting curve (0.30- $0.40^{\circ} \mathrm{C}$ increases every 2 seconds), meaning that only thermocyclers capable of performing high resolution melting curves are suitable for the protocol. A limitation of this study is that we were unable to test the protocol in thermocyclers of different formats, such as those using thermal block formats. However, we did test two similar, but independent, centrifugal PCR machines; we found the same genotypes on both machines, suggesting that any laboratory equipped with a compatible thermocycler would be able to accurately reproduce the results and come to identical allelic discrimination.

Thus, the ACE I/D polymorphism can be properly genotyped by the analysis of the dissociation curve using: 1) the primers described in this study in concentrations greater than, but preferably equal to $200 \mathrm{nM}$ for the three primers; 2) SYBR Green corresponding to $50 \%$ of the final volume; 3) $15 \mathrm{ng}$ of DNA sample with final volume adjusted to $20 \mu \mathrm{l}$ with UltraPure DNase/RNase-Free Distilled Water. DNA amplification can be carried out according to the following protocol: initial denaturation at $95^{\circ} \mathrm{C}$ for 10 minutes, followed by 40 cycles of $95^{\circ} \mathrm{C}$ for 15 seconds and $55^{\circ} \mathrm{C}$ for 1 minute. Melting curve is to be done by cooling the samples to $60^{\circ} \mathrm{C}$ and then slowly heating the tubes up to $95^{\circ} \mathrm{C}$, raising the temperature by $0.35^{\circ} \mathrm{C}$ every 2 seconds (fluorescence is read after every temperature rise).

In addition to this method optimising genotyping, this study also presented a simple protocol for the purification of genomic DNA from buccal cells. Its low cost, ease and safety (i.e., completely non-invasive) combined with high-quality highyield DNA are ideal characteristics for studies with athletes, since it can be done in their own training locations or during competitions, and a large number of samples can be collected on a single day. 


\section{Acknowledgments}

The authors are grateful to all participants who kindly provided their samples for DNA analysis and to Dr. Bryan Saunders for proofreading this article. J. P. L. F. G. receives a scholarship from the Fundação de
Amparo à Pesquisa do Estado de São Paulo (FAPESP: 2012/22516-6). S. B. receives a scholarship from the Coordenaçáo de Aperfeiçoamento de Pessoal de Nível Superior (CAPES:1182744).

\section{Resumo}

Ajuste de um protocolo rápido e simples de PCR em tempo real para a genotipagem do polimorfismo I/D encontrado na gene da enzima conversora de angiotensina

A inserção ou deleção de 288 pb no íntron 16 do gene que codifica a enzima conversora de angiotensina (ECA) foi a primeira variante genética associada com o desempenho físico e uma das mais estudadas nos últimos 15 anos. Carreadores da deleção em pelo menos um dos alelos, podem apresentar maior atividade enzimática, resultando em uma maior resposta vasoconstritora. Estes indivíduos podem também possuir uma melhor resposta ao treinamento de força e potência, assim como carreadores da inserção podem possuir uma melhor predisposição ao treinamento de endurance. Tradicionalmente, para determinar o genótipo do indivíduo (I/I, I/D ou D/D), o método utilizado é o PCR convencional. Este método envolve dois estágios; primeiramente a reação da PCR é realizada e depois o gel de agarose contendo o produto da PCR é submetido à eletroforese tornando possível visualizar por luz UV as bandas de DNA indicando o genótipo. Para o uso desta metodologia em larga escala, como no caso de estudos de associação, utilizados para avaliar a influência da genética no esporte, este duplo processo consumo muito tempo. Este artigo tem como objetivo apresentar um protocolo rápido e eficiente para a genotipagem deste polimorfismo por meio da PCR em tempo real, utilizando DNA genômico coletado de células bucais. 0 protocolo discutido no texto foi inicialmente proposto em 2001, contudo a sua configuração original apresenta limitações e utiliza uma quantidade grande de material. Variáveis do protocolo, tais como: concentração do primer, volume de reação e resolução da curva de dissociação que indica o genótipo foram ajustadas. Após este ajustamento, o protocolo permaneceu efetivo com uma quantidade reduzida de custo, adequado para o uso em estudos em larga-escala envolvendo genética e esporte.

PalavRAS-Chave: Genética; Esporte; Genotipagem; PCR.

\section{References}

1. Guilherme JPLF, et al. Genetics and sport performance: current challenges and directions to the future. Rev Bras Educ Fís Esporte 2014;28(1).

2. Lightfoot JT. Commentary on viewpoint: Perspective on the future use of genomics in exercise prescription. J Appl Physiol 2008;104(4):1249.

3. Pescatello LS. Commentary on viewpoint: Perspective on the future use of genomics in exercise prescription. J Appl Physiol 2008;104(4):1247.

4. Rankinen T, Bouchard C. Gene-exercise interactions. Prog Mol Biol Transl Sci 2012;108:447-60.

5. Roth SM. Perspective on the future use of genomics in exercise prescription. J Appl Physiol 2008a;104(4):1243-5.

6. Roth SM. Last word on viewpoint: perspective on the future use of genomics in exercise prescription. J Appl Physiol 2008b;104(4):1254. 
7. Thomis M. Commentary on viewpoint: perspective on the future use of genomics in exercise prescription. J Appl Physiol 2008;104(4):1251.

8. Timmons JA. Commentary on viewpoint: perspective on the future use of genomics in exercise prescription. J Appl Physiol 2008;104(4):1250.

9. Wagner PD. Commentary on viewpoint: perspective on the future use of genomics in exercise prescription. J Appl Physiol 2008;104(4):1246.

10. Hughes DC, et al. Genetics of muscle strength and power: polygenic profile similarity limits skeletal muscle performance. J Sports Sci 2011;29(13):1425-34.

11. Williams AG, Folland JP. Similarity of polygenic profiles limits the potential for elite human physical performance. J Physiol 2008;586(1):113-21.

12. Gayagay G, et al. Elite endurance athletes and the ACE I allele--the role of genes in athletic performance. Hum Genet 1998;103(1):48-50.

13. Montgomery HE, et al. Human gene for physical performance. Nature 1998;393(6682):221-2.

14. Eynon N, et al. Genes for elite power and sprint performance: ACTN3 leads the way. Sports Med 2013;43(9): 803-17.

15. Fyhrquist F, Saijonmaa O. Renin-angiotensin system revisited. J Intern Med 2008;264(3):224-36.

16. Brewster UC, Perazella MA. The renin-angiotensin-aldosterone system and the kidney: effects on kidney disease. Am J Med 2004;116(4):263-72.

17. Dendorfer A, et al. Pathways of bradykinin degradation in blood and plasma of normotensive and hypertensive rats. Am J Physiol Heart Circ Physiol 2001;280(5):H2182-8.

18. Rush JW, Aultman CD. Vascular biology of angiotensin and the impact of physical activity. Appl Physiol Nutr Metab 2008;33(1):162-72.

19. Puthucheary Z, et al. The ACE gene and human performance: 12 years on. Sports Med 2011;41(6):433-48.

20. Alhenc-Gelas F, et al. Distribution of plasma angiotensin I-converting enzyme levels in healthy men: relationship to environmental and hormonal parameters. J Lab Clin Med 1991;117(1):33-9.

21. Rigat B, et al. An insertion/deletion polymorphism in the angiotensin I-converting enzyme gene accounting for half the variance of serum enzyme levels. J Clin Invest 1990;86(4):1343-6.

22. Domingo R, Sturrock ED, Collins M. ACE activity and endurance performance during the South African Ironman triathlons. Int J Sports Med 2013;34(5):402-8.

23. Ma F, et al. The association of sport performance with ACE and ACTN3 genetic polymorphisms: a systematic review and meta-analysis. PLoS One 2013;8(1):e54685.

24. Cerit M, et al. Relationship between ace genotype and short duration aerobic performance development. Eur J Appl Physiol 2006;98(5):461-5.

25. Costa AM, et al. Association between ACE D allele and elite short distance swimming. Eur J Appl Physiol 2009;106(6):785-90.

26. Gibson NJ. The use of real-time PCR methods in DNA sequence variation analysis. Clin Chim Acta 2006;363 (1-2):32-47.

27. Evans AE, et al. Polymorphisms of the angiotensin-converting-enzyme gene in subjects who die from coronary heart disease. QJ Med 1994;87(4):211-4.

28. Rigat B, et al. PCR detection of the insertion/deletion polymorphism of the human angiotensin converting enzyme gene (DCP1) (dipeptidyl carboxypeptidase 1). Nucleic Acids Res 1992;20(6):1433.

29. Shanmugam V, Sell KW, Saha BK. Mistyping ACE heterozygotes. PCR Methods Appl 1993;3(2):120-1.

30. Glenn KL, et al. An alternative method for genotyping of the ACE I/D polymorphism. Mol Biol Rep 2009;36(6):1305-10.

31. Hiratsuka M, et al. Detection of angiotensin-converting enzyme insertion/deletion polymorphisms using real-time polymerase chain reaction and melting curve analysis with SYBR Green I on a GeneAmp 5700. Anal Biochem 2001;289(2):300-3.

32. Lin MH, et al. Real-time PCR for rapid genotyping of angiotensin-converting enzyme insertion/deletion polymorphism. Clin Biochem 2001;34(8):661-6.

33. Tanaka $\mathrm{C}$, et al. An alternative fast and convenient genotyping method for the screening of angiotensin converting enzyme gene polymorphisms. Hypertens Res 2003;26(4):301-6. 
Guilherme JPLF, et al.

34. Rodriguez-Romo G, et al. Does the ACE I/D polymorphism, alone or in combination with the ACTN3 R577X polymorphism, influence muscle power phenotypes in young, non-athletic adults? Eur J Appl Physiol 2010;110(6):1099-106.

35. Saracevic A, et al. Angiotensin-converting enzyme insertion/deletion polymorphism genotyping error: the cause and a possible solution to the problem. Mol Biol Rep 2013;40(7):4459-63.

CORRESPONDING AUTHOR João Paulo Limongi França Guilherme Laboratório de Nutrição e Metabolismo Aplicados a Atividade Motora Escola de Educação Física e Esporte

Universidade de São Paulo Av. Prof. Mello Moraes, 65 - Cidade Universitária CEP: 05508-030 - São Paulo - SP E-mail: jplfguilherme@hotmail.com
Submitted: 01/19/2015

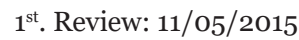

$2^{\text {nd }}$. Review: 01/27/2016

Accepted: 02/04/2016 